\title{
Ruin or Renewal: The United Packinghouse Workers of America and the 1948 Meatpacking Strike in Iowa
}

\author{
BRUCE FEHN
}

AT 12:01 A.M. on March 16, 1948, twenty thousand Iowa members of the United Packinghouse Workers of America (UPWA) walked off their jobs in fifteen plants throughout the state. In doing so, they joined more than eighty thousand other UPWA members nationwide in what became one of the most violent episodes in Iowa's labor history. ${ }^{1}$ Strikers and strikebreakers confronted one another in packing towns throughout Iowa. In Cedar Rapids, Mason City, Ottumwa, Sioux City, and Waterloo, the strike halted production by major employers, affecting even

I want to thank Merle Davis, Marc Linder, Roger Horowitz, Marvin Bergman, Wilson Warren, two anonymous reviewers, and, especially, John Schacht for helpful comments and suggestions. Thanks also to Jeff Buscher for research assistance. Research for this paper was supported by a 1995-96 Iowa Sesquicentennial Research Grant.

1. For analyses of the strike's national development, see Roger Horowitz, "Negro and White, Unite and Fight!" A Social History of Industrial Unionism in Meatpacking, 1930-90 (Urbana and Chicago, 1997), 184-89; and David Brody, The Butcher Workmen: A Study of Unionization (Cambridge, MA, 1964), 232-37. In Iowa, the UPWA struck the following plants: Armour (Sioux City), Bookey (Des Moines), Cudahy (Sioux City), Davis Packing (Estherville), Decker, an Armour subsidiary (Mason City), Des Moines Packing (Des Moines), Glaser Packing (Fort Dodge and Sioux City), John Morrell and Co. (Ottumwa), Rath Packing (Waterloo), Swift and Co. (Perry and Sioux City), Tobin Packing (Fort Dodge and Estherville), and Wilson (Cedar Rapids). Mary Beth Eldridge, The Rath Packing Company Strike of 1948 (n.p., 1990), 3.

THE ANNALS OF IOWA 56 (Fall 1997). CThe State Historical Society of Iowa, 1997. 
people not directly involved. The strike held the attention of local citizens and was front page news in packing-town newspapers. In the most tragic instance of violent altercation on UPWA picket lines, a strikebreaker in Waterloo pulled a pistol and shot UPWA Local 46 member Charles "Chuck" Farrell through the head, killing him instantly. In response, Local 46 strikers went on a rampage, prompting Governor Robert Blue to send $\mathrm{Na-}$ tional Guard troops to Waterloo to maintain order.

This large-scale confrontation between labor and capital evolved in similar ways in Iowa's various packing centers. The strike began relatively peacefully, with local union members even helping companies keep refrigeration and mechanical units in operating condition. Within three weeks, however, Wilson in Cedar Rapids, John Morrell in Ottumwa, and other meatpacking firms established a much harder line with the strikers. Company officials published deadlines in local newspapers after which new workers would be hired to replace striking workers. When strikebreakers did cross pickets lines, often with local police protection, unionists reacted by harassing them as well as the companies' supervisory personnel.

From late March to mid-April, companies sought and obtained court injunctions to force UPWA members to quit their more aggressive tactics against strikebreakers. Rather than capitulating to these legal maneuvers, the strikers adjusted their tactics. Instead of relying so much on mass picketing, they confronted and intimidated would-be strikebreakers at places away from the picket line. These incidents heightened antagonisms between strikers, company officials, police, and strikebreakers. As UPWA members grew angrier, it became more difficult for union leaders to control them. This created the potential for larger-scale, more violent confrontations. In Waterloo, Chuck Farrell's killing ignited that potential.

The 1948 strike had a mixed legacy for the long-term vitality of the United Packinghouse Workers. For many members, though, union activities, undertaken in the face of corporate power, reinforced their allegiance to the UPWA and to one another. In numerous incidents, no one of which may have been definitive in itself, UPWA members displayed their solidarityon the picket line, in confrontations with strikebreakers and po- 
lice, and through acts of personal generosity as strikers helped each other weather seventy-five grueling days without a paycheck. These episodes reinforced many UPWA members' union allegiance, which they had developed as the great industrial union movement swept through the meatpacking industry. Their commitment to oppositional strength equipped Iowa's packinghouse workers to win back a significant measure of the power most UPWA local unions lost after the 1948 meatpacking strike.

UPWA LOCAL UNIONS' oppositional strength, and the seeds of union resurgence following the 1948 strike, were contained in the local union structure that UPWA pioneers had built to transform working conditions in Iowa's meatpacking industry. During the late 1930s and 40s, UPWA activists built powerful shop-floor organizations, which they then used to pressure company supervisors to resolve grievances. Frequent displays of strength and mutual support through work slowdowns or walkouts demonstrated local unions' power and helped create a strong sense of solidarity among UPWA members inside packinghouses. $^{2}$

Local union members' sense of solidarity was laced with an oppositional outlook. They viewed management as a force responding almost exclusively to collective pressure administered at the point of production. In other words, UPWA members came to understand that packing companies responded to workers' interests only if workers threatened the owners' profit margin through collective activity. Eventually, this sense of oppositional strength spread beyond the packing plants and UPWA

2. On the power of UPWA locals' shop-floor organizations, see Horowitz, Negro and White Unite and Fight, chaps. 2-5 passim; Paul Street, "Breaking Up Old Hatreds and Breaking Through the Fear: The Rise of the Packinghouse Workers Organizing Committee in Chicago, 1933-1940," Studies in History and Politics 5 (1986), 69-71; and Rick Halpern, "Race and Radicalism in the Chicago Stockyards: The Rise of the Chicago Packinghouse Workers Organizing Committee," in Unionizing the Jungles: Labor and Community in the TwentiethCentury Meatpacking Industry, ed. Shelton Stromquist and Marvin Bergman (Iowa City, 1997), 83-85. On the "hardline stance" of Local 1 union founders in Ottumwa, see Wilson J. Warren, "The Heyday of the CIO in Iowa: Ottumwa's Meatpacking Workers, 1937-1954," Annals of Iowa 51 (1992), 368-72. 
union halls. ${ }^{3}$ To a significant degree, it permeated UPWA families and their communities. Consequently, in major strikes, such as the one in 1948, UPWA locals gained support for the union cause from many townspeople and farmers and some local businesspeople.

To comprehend the sources of union solidarity and oppositional outlook among UPWA members, one must first understand how union activists went about undermining what was often described as an outrageous system of exploitative labor within the packinghouses of Iowa. "Slave labor is what it was," recalled Louis Tickal, who began working at Sinclair Packing (later Wilson and Company) in Cedar Rapids in 1929. The company sometimes required employees to work sixteen-hour days without overtime compensation. Tickal later told interviewers, "without a union, we'd never have survived down there. They [the company] wouldn't kick you out, they'd kill you" with increased labor demands that broke workers physically and emotionally. ${ }^{4}$

In oral history testimony, many workers recalled abuses and indignities perpetrated by supervisory personnel. Before the UPWA organized Iowa plants, workers had little job security. Company foremen typically exercised firm control over hiring, firing, and job placement, and they often made employment decisions based on favoritism. That set the stage for discriminatory employment practices based on race, age, and sex. Viola Jones, a Waterloo Rath worker, remembered that some foremen at Rath "were like bears." She watched while a foreman fired an older woman who could not keep up the demanding pace

3. Jeremy Brecher, Strike! (Boston, 1972), 291-93; Warren, "Heyday of the CIO," 372-73. I purposefully avoid using the terms oppositional consciousness and oppositional culture, which have been brilliantly employed by George Lipsitz, A Life in the Struggle: Ivory Perry and the Culture of Opposition (Philadelphia, 1988); and Robin D. G. Kelley, Hammer and Hoe: Alabama Communists during the Great Depression (Chapel Hill, NC, 1990), chap. 5. Rather, I use the terms oppositional outlook and solidarity, which more accurately capture UPWA workers' understanding that through collective action, and the threat thereof, they were able to influence packinghouse management's behavior and decision making.

4. Louis Tickal, interview, Cedar Rapids, 17 April 1986, United Packinghouse Workers of America Oral History Project (hereafter UPWAOHP), State Historical Society of Wisconsin, Madison, Wisconsin. 
of work. "She stood there and cried." Local 46 union founder Velma Otterman Schrader, who also worked at Waterloo Rath, recalled how a foreman replaced an older worker with a younger woman to whom the foreman "took a fancy." As he walked through Schrader's department to decide where to place the younger woman, "the older women just put their heads down and twisted wieners to beat the band."

Foremen exercised rigorous and arbitrary control over the shop floor. Alvin Edwards recalled how he once "took sick" while at work at the Swift plant in Sioux City. The foreman told him that he would either continue work or be fired. At Wilson and Company in Cedar Rapids, one foreman would not allow women to chew gum. He also appointed a woman to time her fellow workers' restroom visits. "If [that woman] didn't like you, she didn't let you go until she was damn good and ready." As a result of such restrictions on workers' movements, a woman with bladder trouble wet her pants. Another worker miscarried after she was not allowed to leave work. Oral history testimony indicates such examples of humiliation and harassment at Rath echoed throughout Iowa prior to the successful unionization of the meatpacking industry. ${ }^{6}$

From its inception in 1937, the UPWA (at first called the Packinghouse Workers Organizing Committee, or PWOC) began to win workers' allegiance by demonstrating its power to prevent company abuses. In the 1930s and 40s, union activists from Cedar Rapids, Austin (Minnesota), and Chicago organized workers in Waterloo's Rath Packing Company, Ottumwa's John Morrell and Company, Mason City's Jacob Decker, and Sioux

5. Viola Jones, interview, Waterloo, 6 May 1986, and Velma Otterman Schrader, interview, Waterloo, 7 May 1986, UPWAOHP; Gregory Zieren, "'If You're Union, You Stick Together': Cedar Rapids Packinghouse Workers in the CIO," Palimpsest 76 (1995), 36-37, 40-42. On the foreman's power at this time in the John Morrell plant in Ottumwa, see Wilson J. Warren, "The Welfare Capitalism of John Morrell and Company, 1922-1937," Annals of Iowa 47 (1984), 509-10.

6. Alvin Edwards, interview, Sioux City, 1 July 1986; Helen Zrudsky, interview, Cedar Rapids, 18 April 1986; Viola Jones, interview, UPWAOHP. On incidents of sexual harassment, see Velma Otterman Schrader, interview, UPWAOHP; Velma Otterman, interview, Waterloo, 30 June 1981; and Mary Ashlock, interview, Mason City, 17 November, 1981, Iowa Labor History Oral Project (hereafer ILHOP), State Historical Society of Iowa, Iowa City. 
City's Armour, Swift, and Cudahy packing plants. Union organization and recognition brought benefits to workers, including higher wages, grievance procedures, improved working conditions, and, above all, a strictly enforced seniority system.?

Local unions won these benefits by installing and activating powerful steward systems inside Iowa's UPWA-organized packinghouses. These steward systems became so tightly organized and controlled by union members that a dispute in one part of a packinghouse could quickly lead to a shutdown of the plant's entire operation. The threat of meat spoilage put tremendous pressure on company officials to settle grievances quickly. With a seniority system securely in place, the power of foremen and other supervisory personnel was significantly curtailed. If supervisors threatened workers with discharge, they had to have a very good reason for doing so. Formal grievance procedures enabled employees to seek redress if they felt they had been unfairly discharged or otherwise mistreated. If supervisors were intransigent, local unions could, and often did, employ their shop-floor power to interrupt production. ${ }^{8}$

In the years prior to the 1948 strike, local union members had grown accustomed to using strikes to organize plants, force consideration of union demands, and impress fainthearted workers with union power. Members came to regard strikes, whether local or nationwide, as a legitimate and required method of influencing company behavior. "We were really one for all and all for one," recalled Fred Nolting of UPWA Local 46 in Waterloo. "If one of our members got treated unfairly, unjustly, without due process being followed, we just had a confrontation."

Union activists came to regard strikes, further, as a means of imbuing workers' consciousness with a sense of solidarity.

7. Horowitz, Negro and White, Unite and Fight, chaps. 2-5 passim; Bruce Fehn, "'Chickens Come Home to Roost': Industrial Reorganization, Seniority and Gender Conflict in the United Packinghouse Workers of America, 1956-1966," Labor History 34 (1993), 328-30.

8. Horowitz, Negro and White, Unite and Fight, chaps. 2-5 and 9 passim; idem, "'It Wasn't a Time to Compromise': The Unionization of Sioux City's Packinghouses, 1937-1942," Annals of Iowa 50 (1989/1990), 241-68; Zieren, "'If You're Union, You Stick Together,'" 37-38, 40-42.

9. Fred Nolting, interview, Waterloo, 21 June 1981, ILHOP. 
As Anthony "Tony" Fetter of UPWA Local 3 in Cedar Rapids observed, "In the old days instead of arguing a grievance [union stewards would] just say, 'Okay, we'll shut 'er down.'" According to Fetter, "wildcat strikes used to be taken for granted. You could shut the plant down or shut the department down." In his oral history of Iowa labor, Shelton Stromquist assembled workers' testimony to show how union leadership in Ottumwa Local 1 used wildcat strikes regularly "to whack 'em" and let management know that "you're running the show."10

THE NATIONWIDE 1948 STRIKE sorely tested the UPWA's ability to use strikes to raise wages, improve working conditions, and signal management that the UPWA demanded a hand in "running the show." Two years earlier, the UPWA had won a nationwide strike that led to a significant wage hike for its members. The union's 1946 walkout, however, took place under circumstances substantially different than those surrounding the 1948 strike. For one, the 1946 strike was part of the largest strike wave in United States history, and UPWA members benefited from the collective action of 4.6 million people who, at various times that year, stopped work nearly five thousand times. Even more importantly, the UPWA's archrival, the Amalgamated Meatcutters and Butcher Workmen of North America, also went on strike in 1946, thereby confronting the great meatpacking chains of Swift, Armour, Cudahy, Wilson, and John Morrell with an almost wholly united packinghouse workforce. Neither condition held in 1948. The UPWA struck out on its own at a time that some in the UPWA's leadership -including President Ralph Helstein - did not regard as propitious. ${ }^{11}$

Why, then, did the UPWA leadership in Chicago decide to call a nationwide strike in 1948 ? News accounts at the time

10. Shelton Stromquist, Solidarity and Survival: An Oral History of Iowa Labor in the Twentieth Century (Iowa City, 1993), 160, 207. On the use of wildcat strikes in Iowa packinghouses, see also interviews with Bruce Nolan, Richard Lindner, Eugene Weems, and Jack McCoy, quoted ibid., 99-100, 107-8, 155, 206-7. On Ottumwa Local 1's shop-floor power and use of strikes and job actions, see Wilson J. Warren, "Heyday of the CIO," 371-72.

11. James R. Green, The World of the Worker: Labor in Twentieth-Century America (New York, 1980), 194; Ralph Helstein, interview, Chicago, 12 May 1983, ILHOP. 
focused on the dispute over wages as the key issue motivating union leaders to call for a nationwide strike. ${ }^{12}$ Indeed, wages were a key factor. With the abolition of price controls after the war, living costs were rising sharply. Workers wanted a raise. Union leaders pointed out that in 1948 a single breadwinner needed to earn $\$ 1.65$ per hour in order to support a family of four, yet two-thirds of all packinghouse workers earned less than $\$ 1.10$ per hour. ${ }^{13}$

Wages were not, however, the only concern. Some union leaders were motivated, to a significant degree, by a desire to challenge the recently enacted Taft-Hartley Act. Passed in 1947 in the wake of the 1946 strike wave, Taft-Hartley severely restricted union activities. With its requirement of prior notice for strike action, the act threatened the UPWA's traditional base of strength: the ability to stop production at a moment's notice and catch the company by surprise. ${ }^{14}$ Frank Ellis, head of the UPWA's organization department, warned the union's executive board that Taft-Hartley "has as one of its main objectives the purpose of undermining union authority and disintegrating our union wherever possible." The law, he charged, "opens the door wide for various forms of company-inspired attacks inside our local unions." Ellis's viewpoint reflected that of District 3 leadership, headquartered in Des Moines, as well as many of Iowa's union rank-and-file. Iowa UPWA members voted to strike in part because they wanted to prevent companies from "dismantl[ing] the position of strength the unions had achieved on the shop-floor."15

12. See, for example, Business Week, 28 February 1948, 91; Chicago Daily Tribune, 16 March 1948; New York Times, 17 March 1948; "Strike Threatens Tie-up of Meat Supply," folder 8, box 449, United Packinghouse Workers of America Records, State Historical Society of Wisconsin, Madison, Wisconsin.

13. Ralph Helstein, "The Packinghouse Workers' Case," New Republic, 29 March 1948, 7; The Packinghouse Worker, 9 July 1948, 3.

14. Horowitz, Negro and White, Unite and Fight, 181; Stromquist, Solidarity and Survival, 176.

15. "Organization Department Proposals Submitted to International Executive Board," 16 September 1947, UPWA Records. See also Stromquist, Solidarity and Survival, 176; and Horowitz, Negro and White, Unite and Fight, 183. 
In early March 1948, UPWA members in Iowa and other states prepared to quit work in order to attain a wage increase and demonstrate disapproval of Taft-Hartley. By that time, the efforts of the UPWA's international leadership to come to an agreement with the Big Four meatpacking companies (Armour, Cudahy, Swift, and Wilson) were on the verge of collapse. ${ }^{16}$ The UPWA leadership had demanded a twenty-nine-cent hourly wage increase; Big Four negotiators had countered with an offer of nine cents. When negotiations failed to bridge the wage impasse, UPWA members voted overwhelmingly, by a twenty to one margin, to go out on strike. On March 16, Iowa's twenty thousand UPWA members joined eighty thousand members in other states in a walkout that shut 65 plants across the country. ${ }^{17}$

DURING THE STRIKE'S FIRST FEW DAYS, union solidarity was relatively easy to maintain in Iowa's packing towns. Union rank-and-file followed local strike committees' orders to set up and maintain picket lines and sheds around packing facilities. UPWA Local 1 strikers in Ottumwa established a picket line six and one-half miles long around the entire John Morrell plant. Picketers required company officials to show passes issued by the union before they could enter or leave the plant. In Waterloo, Local 46 picket captains outside Rath distributed signs announcing to passersby, "Packing House Workers Are \#1!"; "We March Against Hunger Cuts"; "No Raise! No Work!"; "Watch Us Grow." A Local 89 sign placed outside the Swift plant in Des Moines' southeast "bottoms" area read "Closed for Alteration of Swift's Thinking!" Cedar Rapids Local 3 members stationed picket sheds around the Wilson and Company plant, and strike leaders assigned members around-the-clock shifts for walking the line. Picket captains roamed the plant's perimeter to ensure that sixteen pickets walked at each of the company's

16. In a system known as "pattern bargaining," contract agreements with the Big Four established the pattern for wages and work rules subsequently negotiated at independent packers such as Rath Packing Company in Waterloo. 17. Leslie F. Orear and Stephen H. Diamond, Out of the Jungle: The Packinghouse Workers' Fight for Justice and Equality (Chicago, 1968). 


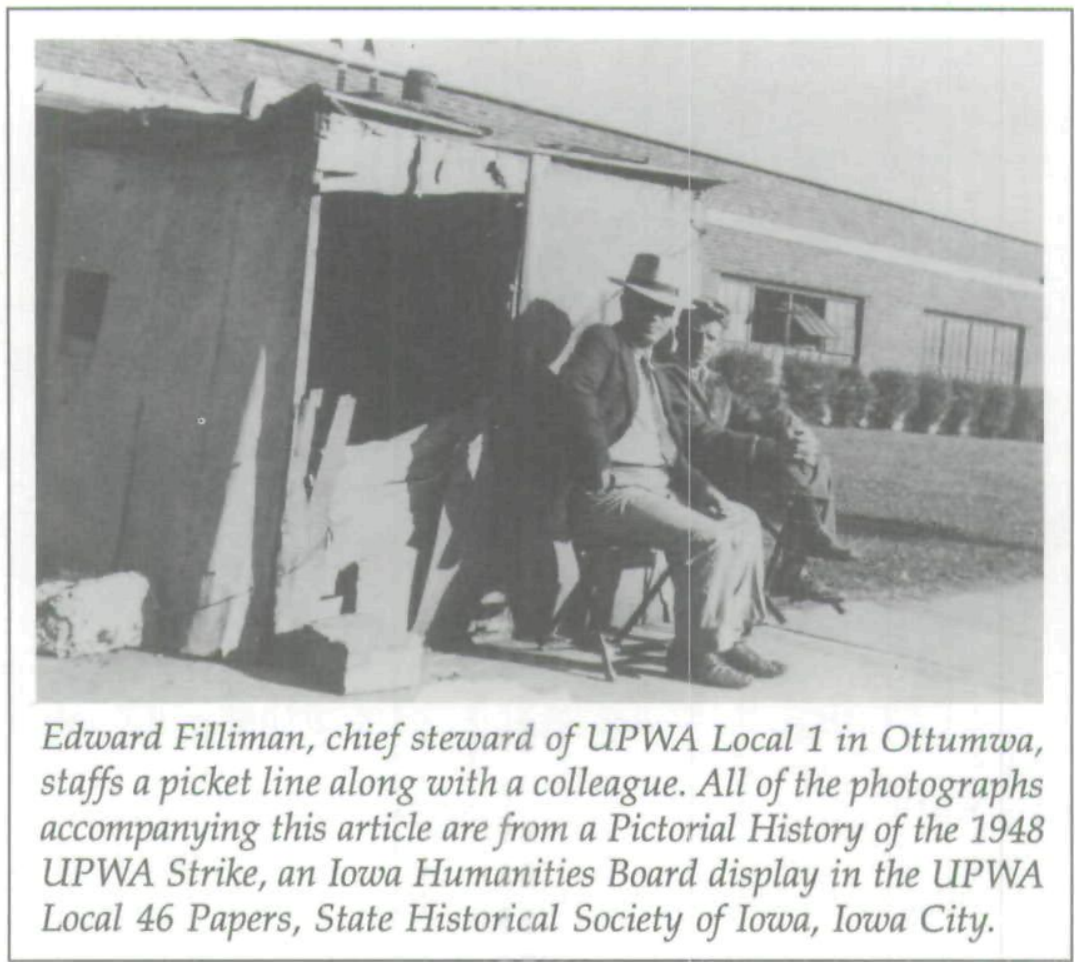

thirteen gate entrances. ${ }^{18}$

Meanwhile, strikers sought community support for the union struggle. Mickey Lockhart and other Local 3 members in Cedar Rapids "went out begging . . . for day old goods" and went to neighborhood grocery stores to convince them not to buy Wil-

18. U.S. Congress, House, Committee on Expenditures in the Executive Departments, Investigation as to the Administration of the Laws Affecting Labor Disputes, Interstate and Foreign Commerce and the Anti-Racketeering Statute, the Interstate Transportation of Pickets, and the Activities of the Department of Justice, in Connection with Strikes in the Meat-Packing Industry in Twenty States. Hearings before a Subcommittee of the Committee on Expenditures in the Executive Departments, 80th Cong., 2d sess., 20 May 1948, 166; idem, Twenty-first Intermediate Report, Report 2464, 80th Cong., 2d sess., 20 December 1948, 10; The Packinghouse Worker, 2 April 1948, 7; Warren, "Heyday of the CIO," 376; Mary Eldridge, rough draft of manuscript for her history of The Rath Packing Company Strike of 1948, part 1, p. 26, folder 29, box 2, Local 46 Papers, State Historical Society of Iowa (SHSI), Iowa City. See also Sister John Marie Daly, "History of Unionization, Waterloo, Iowa," p. 44 , folder 17 , box 1 , ibid. 
son products. "We done such a good job in local stores," Lockhart recalled, "that Wilson had a hard time getting some of their orders back" after the strike ended. Strikers in Cedar Rapids accepted the Kacere family's offer to set up a strike kitchen in their cafe, to which local merchants contributed provisions. While the strike kitchen supplied food and coffee, picketers sang songs to keep up their spirits as they spent monotonous hours on picket duty. ${ }^{19}$

In the first week or two of the strike, UPWA members maintained relatively positive working relationships with local municipal officials, police, and even packinghouse management. Police in Sioux City presented a check for two hundred dollars to the UPWA's strike fund. In Waterloo, Local 46 and Rath Packing Company officials entered a "gentlemen's agreement" to maintain plant equipment and ensure that meat did not spoil. When there were trucks or trains to be unloaded, Rath asked the union to send workers to the plant, and the union cooperated with the company's requests. To facilitate these efforts, Local 46 issued passes to supervisory personnel, union powerhouse workers, and union watchmen who entered the plant to maintain refrigeration equipment and do safety inspections. In an attempt to promote good will with the community and law enforcement officials, Local 46 invited Waterloo's mayor, Bailey Barnes, and the Black Hawk County sheriff to speak at the union's mass rally on the eve of the strike. Local 46 pledged to city officials that it would monitor the conduct of members on the picket line, and the sheriff deputized union members who pledged to prevent violence and maintain order. ${ }^{20}$

However, peaceful relationships between management and members of Iowa's UPWA local unions quickly unravelled as negotiations between the UPWA and the Big Four went nowhere. Before the UPWA strike began, meatpackers reached agreement for a nine-cent per hour wage increase with the UPWA's two chief rivals in the industry: the National Brother-

19. The Packinghouse Worker, 7; Zieren, "'If You're Union, You Stick Together,'" 42-44.

20. Daly, "History of Unionization," 44; Eldridge, draft of history, part 1, pp. 15-16 and 26, and part 2, p. 11; idem, Rath Packing Company Strike, 6. 
hood of Packinghouse Workers (NBPW) and, more significantly, the Amalgamated Meat Cutters and Butcher Workmen of North America (AMCBW). These agreements with the AMCBW and NBPW stiffened company resolve to hold firm, not surprisingly, since those two unions represented workers in thirty-four Big Four units. Those plants were not affected by the UPWA walkout and, in historian David Brody's phrase, "ran full blast." ${ }^{21}$

The companies' stiffened resolve was revealed further in the course of government mediation efforts. At those mediation meetings, company representatives were intransigent, refusing to make a single concession beyond what they had offered in negotiations prior to the strike's commencement. On April 8 a board of inquiry, appointed by President Truman to study the strike's effect on national health and safety, further reduced prospects for a quick settlement. It reported that the nine-cent per hour wage increase the packers had originally offered and successfully negotiated with the AMCBW and the NBPW was "adequate compensation for changes in the cost of living since the last wage increase of six cents per hour in June 1947." This indicated that the president would not step in to end the strike and impose an arbitrated settlement. ${ }^{22}$

SUCH DEVELOPMENTS on the national scene coincided with a rapid deterioration of the amity that had prevailed at Iowa strike sites during the first three to five weeks of the strike. Throughout the state, companies began to challenge unions with a series of moves that had the potential to weaken strikers' resolve. First, companies tried to resume operations by attempting to move livestock in or meat products out of packing facilities. ${ }^{23}$ Then, company officials threatened to hire replacement workers unless the strike came to a swift conclusion. By mid-April, the latter was more than a threat; strikebreakers were crossing

21. Brody, The Butcher Workmen, 233.

22. Business Week, 17 April 1948, 106-7; Brody, The Butcher Workmen, 233-34; Eldridge, Rath Packing Company Strike, 8.

23. Cedar Rapids Gazette, 24 and 25 March and 3 April 1948; Sioux City Journal, 20 March 1948; Mason City Globe-Gazette, 14, 15, and 16 April 1948; Ottumwa Courier, 8 April 1948. 
picket lines, sometimes under the protection of local police. Management also sent letters to workers and had supervisory personnel approach union members, both in an attempt to entice them back to work. ${ }^{24}$

To bolster solidarity and display continuing union strength, UPWA members countered with mass picketing, attacks on company property, and intimidation of would-be strikebreakers. In Ottumwa, strikers had picketed the John Morrell and Company plant peacefully for three weeks. On April 6, however, when management informed Local 1 that it would begin to move meat out of the plant, officers and members resorted to more physically aggressive tactics. Immediately, Edward Filliman, Local 1's chief steward, announced in the pages of the Ottumwa Courier that "any attempt to move meat out will result in trouble - plenty of it - and there would be no trouble ... if the company didn't try to move meat." The next day UPWA pickets illegally occupied company property as they stood on railroad tracks to prevent trains from shipping meat. On April 8 , union members piled logs, sandbags and other debris underneath railroad cars, painted "SCAB MEAT" on the sides of the cars, and allegedly set a fire beneath them. "They did this," according to testimony at a U.S. House Subcommittee hearing on the strike, "in the presence of about 16 local police officers who were within 100 yards of the scene but who made no attempt to restrain the activity." 25

To overcome unionists' ability to keep strikebreakers out of the plants and prevent materials from moving in and out, meatpacking firms sought and obtained court injunctions designed to reduce the unions' strength on picket lines. In late March a state district court issued an injunction to prohibit mass picketing by Local 38 union members in Mason City, who had been able to prevent trucks and trains from entering or leaving the Decker plant. On April 9 another district court

24. Cedar Rapids Gazette, 12 April 1948; Waterloo Courier, 18, 19, and 21 April 1948; Mason City Globe-Gazette, 15 and 16 April 1948.

25. U.S. Congress, House, Committee on Expenditures in Executive Departments, Twenty-first Intermediate Report, 10; U.S. Congress, House, Investigation as to the Administration of the Laws Affecting Labor Disputes, 166-75; Ottumwa Courier, 8 April 1948. 
issued a restraining injunction, restricting Ottumwa Local 1 to five pickets at each gate at John Morrell and Company. The injunction also instructed pickets not to use barricades and to use only "peaceful persuasion" in their interaction with persons trying to enter the plant. In a similar move, a district court judge in Waterloo issued an injunction on April 17 ordering Local 46 strikers not to interfere with individuals entering or departing the Rath plant. As in Mason City and Ottumwa, the injunction ordered them not to inhibit the movement of trucks or trains and restricted the number of pickets Local 46 could deploy at the company's gates. ${ }^{26}$

In the face of injunctions to reduce their picket lines' effectiveness, union members turned increasingly to acts of intimidation to discourage strikebreakers and frighten supervisory personnel. Aggressive acts directed at strikebreakers in Ottumwa were so frequent that on April 22 the Ottumwa Courier reported that "lawless goon squads are patrolling the city streets and neighboring highways, to terrorize persons connected with John Morrell \& Co." Local union members also tried to intimidate those who did business with John Morrell. On April 16, for example, they picketed the owner of an Ottumwa service station who had entered the plant to repair company vehicles. In Mason City, after courts issued injunctions and restraining orders, Juanita Barragan and Isabel Gomez were arrested and later fined for attacking a woman who tried to cross the picket line at the Decker plant. ${ }^{27}$

26. The Packinghouse Worker, 9 July 1948; Wilson, "Heyday of the CIO," 377; Mason City Globe-Gazette, 29 March 1948; Ottumwa Courier, 9 and 23 April 1948; Waterloo Courier, 18, 19, and 21 April 1948; Cedar Rapids Gazette, 28 March and 18 and 19 April 1948; Sioux City Journal, 1 and 2 May 1948.

27. Ottumwa Courier, 22 April 1948; Warren, "Heyday of the CIO," 377-78; U.S. Congress, House, Committee on Expenditures in Executive Departments, Investigation as to the Administration of the Laws Affecting Labor Disputes, 167; Mason City Globe-Gazette, 15, 16, and 28 April 1948. There was a clear pattern during the 1948 strike of Iowa's UPWA women intimidating women strikebreakers. On women's contributions to the 1948 strike and its impact on the union's women's rights movements, see Bruce R. Fehn, "Striking Women: Gender, Race, and Class in the United Packinghouse Workers of America, 1938-1968" (Ph.D. diss., University of Wisconsin-Madison, 1991), 211-12ff. 
As company officials reopened plants and courts issued injunctions, the need for worker solidarity became increasingly obvious to the workers themselves. Police activities implemented to break the strike also heightened union members' oppositional outlook. In Waterloo, Local 46 president Leo Guynn told his union brethren that Waterloo's city officials had breached their "good faith" agreement with the union that the latter would be responsible for policing the behavior of its members and maintaining order on the picket line. City officials who had earlier deputized union members to police the behavior of their fellow union rank-and-file were now accused by Guynn of "aiding and abetting strike breaking." In a remark that bespoke union members' perception of collaboration between the government and the company, Guynn claimed that Local 46 members did not "believe the taxpayers will sanction the use of their police force as a strike breaking agency for private industrial interests." To protest the use of police to aid the company and assist strikebreakers, Local 46 members returned the deputy badges that had represented their commitment to maintain order on the picket line. ${ }^{28}$

Company efforts to break the strike, along with the collaboration of city and state officials, required union leaders to constantly bolster worker resolve. To maintain solidarity and keep up members' spirits, union officers and activists talked tough and told members to close ranks and stand firm. UPWA officials from Chicago appeared in Iowa packing towns to help maintain strikers' morale. In late March field representative Russell Lasley, a founding member of Waterloo Local 46, told Local 34 strikers in Mason City, "we're going to have to do something about these city police who sit around the main gate. I guess they're there to scare us. But they'll find out we don't scare." At a union meeting in Waterloo on April 18, the day after the Rath plant reopened, A. T. Stephens, the UPWA's District 3 director, told Local 46 members in Waterloo, "I've never seen this piece of paper [the court injunction] butcher any cattle and I've never seen it operate a sliced bacon machine." ${ }^{\prime 29}$

28. Waterloo Courier, 18 April 1948; Eldridge, draft of history, part 1, pp. 26, 28.

29. Mason City Globe-Gazette, 27 March 1948; Waterloo Courier, 19 April 1948. 
With this kind of encouragement, union members became increasingly hostile in words and actions directed at police and strikebreakers. Strikers by now regarded police as collaborators in company efforts to defeat the strike. In Waterloo, Local 46 members used a loudspeaker to shower strikebreakers and police officers with strings of epithets. In a reference to Waterloo's Mayor Barnes and the police force, one picket at the loudspeaker announced, "here comes Bailey Barnes Boy Scouts. It won't be long now until those stinkin rats [i.e., the strikebreakers] will be crawling out of their holes. . . . There comes a couple of them out the door now." Strikers also used the loudspeaker to let strikebreakers know that they would suffer for their actions. A union member warned them that "a Scab is branded. He's branded deep. He's branded for many years to come. You don't forget that you had a knife stuck in your back. ... You remember it for years." On April 19, Black Hawk County obtained an injunction prohibiting Local 46 from using loudspeakers. ${ }^{30}$

THE INJUNCTIONS, confrontations with police and strikebreakers, long hours on picket duty, and the pinch of weeks without a paycheck exacted a tremendous toll on UPWA members and strained union solidarity. In Iowa's packing towns the strike became a family affair as the homes, cars, and household goods that family members had labored to attain became threatened with repossession. Local union welfare committees supplied desperate workers with small loans and food vouchers. However, according to one striker, "there just wasn't that much money there." As rent and utility bills went unpaid, strikers' families found themselves without basic utilities or threatened with eviction from their homes. "I thought we were going to starve to death," Local 46 member Viola Jones recalled. ${ }^{31}$

For some union members, the economic strain overwhelmed union commitments and perhaps even their sense of self-respect.

30. Pictorial History of the 1948 UPWA Strike, panel 3, Iowa Humanities Board display, Gene Redmon, project director (hereafter cited as IHB display), UPWA Local 46 Papers; Eldridge, draft of history, part 1, p. 33.

31. James Hamlyn, interview, Waterloo, 25 June 1981, ILHOP; Cedar Rapids Gazette, 23 April 1948; Viola Jones, interview, UPWAOHP. 
They went back to work. "When people are desperate for work," Cedar Rapids Wilson Local 3 veteran Frank Hlavacek observed, "they'll go in there. It don't make no difference, your best friend will go in there." Even veteran, committed union members, such as Everett Dietz, seriously considered returning to work to support their families. At the last moment, Everett's brother, a founding member of Waterloo Rath Local 46, loaned him money. Thus aided, he was able to resist the temptation to cross the greatly reinforced picket line that Local 46 members had by then established around the Rath plant. ${ }^{32}$

Union members and supporters displayed solidarity with acts of personal generosity, relying on one another for help along with assistance from community agencies and nonunion members of their local communities. In packing towns throughout the state, union members solicited food donations from merchants and citizens and asked them to boycott meat company products. Some of Sioux City's wholesale distributors responded with donations of vegetables and ground meat. Also in Sioux City, union members visited local taverns, distributed leaflets explaining the union position, and asked patrons to donate to the Sioux City union's strike funds. In the South Bottoms neighborhood in Sioux City, where many packinghouse workers resided, trade unionists implemented an effective "don't buy" campaign against Swift, Armour, and Cudahy. Corner grocery stores, which checkered the South Bottoms area, liberally extended credit to strikers. One Sioux City physician, in response to union appeals, offered strikers his services free of charge. ${ }^{33}$

Union activists also organized shows and moments of theater both to lift strikers' spirits and to win community support. In Waterloo, a brass band consisting of Local 46 members entertained at union meetings and on the picket lines. According to one student of the strike in Waterloo, "people from all over town came to see what would happen next and be entertained."

32. Frank Hlavacek, interview, Cedar Rapids, 17 April 1986, UPWAOHP; Everett Dietz, interview, Waterloo, 6 May 1986, UPWAOHP. On mass picketing in Waterloo, see Waterloo Courier, 18, 19, and 21 April 1948.

33. Stromquist, Solidarity and Survival, 185; The Packinghouse Worker, 2 and 16 April 1948. 


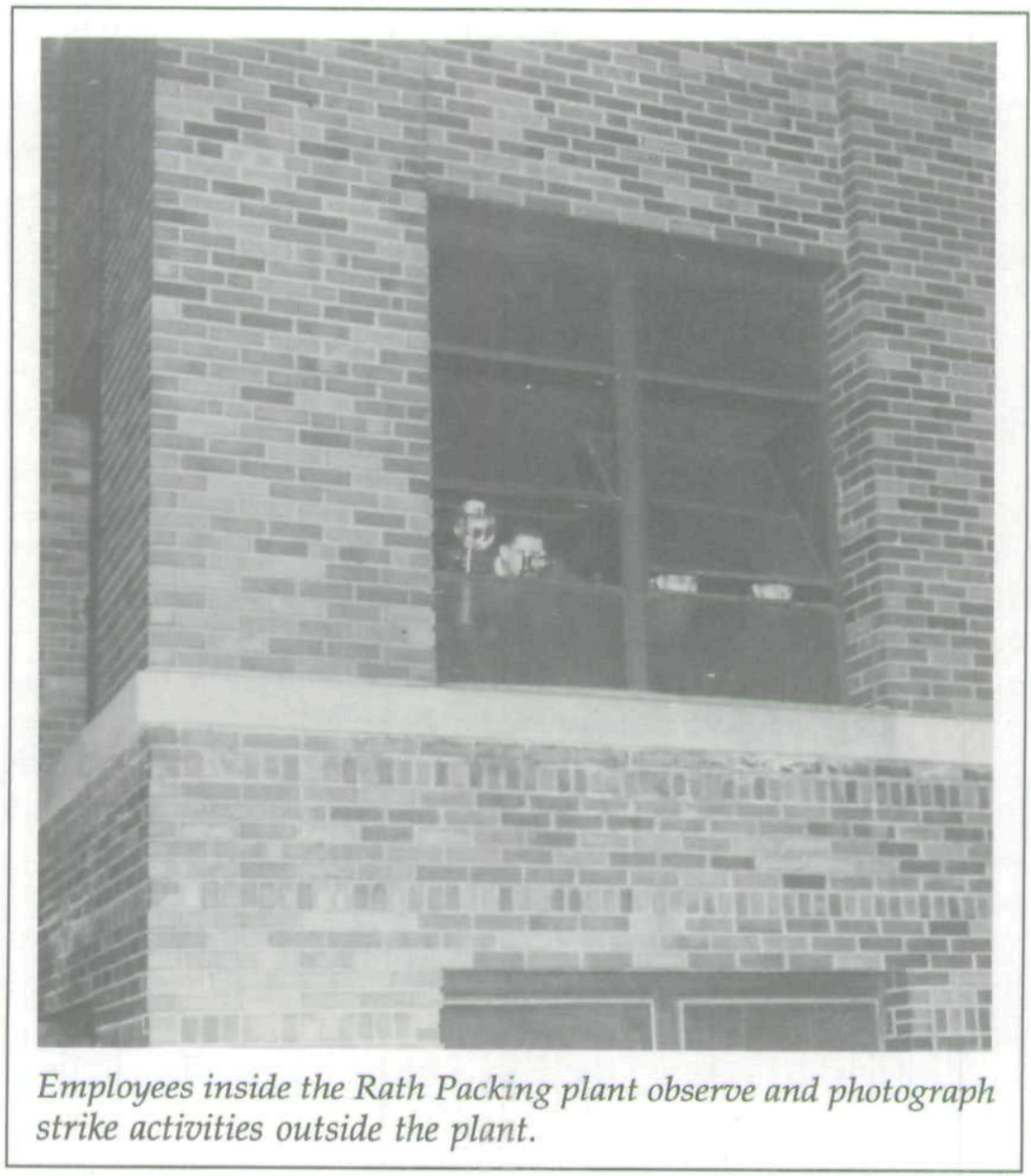

On May 6, three days after Rath announced an official end to the prevailing contract, union members staged a mock funeral and burial of the contract. A worker's black panel truck was decorated as a hearse. Draped in black and carrying a plywood coffin with the contract's "remains," it was driven several blocks to the steps of the union hall. Men wore suits and women carried "armfuls of rhubarb leaves for flowers." At the union hall the contract "lay in state" as mourners passed by and derisively wailed at their loss. One worker read a long-winded "eulogy" that detailed the contract's features. The reading delighted onlookers. Some observers, however, were not so amused. From 
windows high in the Rath Packing Company office building across from the union hall, Rath officials filmed and photographed the proceedings. ${ }^{34}$

At the end of April, as the strike entered its sixth week, it became clear that the companies, rather than negotiating, were intent on breaking union solidarity and imposing a settlement on the UPWA. Companies increased the pressure by running advertisements in local newspapers, encouraging striking workers to return to work. On April 29 and 30, for example, Wilson ran large advertisements in the Cedar Rapids Gazette, inviting all workers to return to the plant and threatening the loss of their jobs if they did not. The offer included the original nine-cent wage hike offer, with the same rights that prevailed before the strike. Wilson claimed that the decision to reopen was driven by losses to farmers, employees, and the company, and that company officials refused arbitration because management could never allow a third party to dictate company costs. Wilson declared that it had "no intention" of budging on a maximum wage hike of nine cents per hour. To entice workers into the Decker plant in Mason City, the company placed advertisements promising ten-hour workdays, seven days per week, with doubletime and overtime. While the companies enticed replacement workers and declared their refusal to reopen negotiations, they also took more drastic measures to import strikebreakers. In Waterloo and Cedar Rapids, for example, both Rath and Wilson hired private buses to transport strikebreakers into the plant. ${ }^{35}$

By early May, as the strike entered its eighth week, UPWA members in Iowa adopted more drastic measures of their own to counter company maneuvers to bring strikebreakers across picket lines. From packing towns throughout Iowa came reports of union members punishing workers who crossed lines, thereby serving notice to others that they would pay a price if they tried

34. Eldridge, draft of history, part 1, pp. 47, 53; IHB display, panel 7.

35. Cedar Rapids Gazette, 29 and 30 April 1948; The Packinghouse Worker, 30 April 1948; Velma Wetzel, interview, Cedar Rapids, 12 October 1979, ILHOP. In Waterloo, the Rath Company resorted to private buses because when city buses arrived as usual at plant gates, UPWA members boarded them and occupied the seats during the buses' entire routes. Of course, this discouraged replacement workers from getting on the buses. Waterloo Courier, 22 April 1948. 
to cross. ${ }^{36}$ On May 4, for example, the Cedar Rapids Gazette ran a photo of a woman striker from Local 3 confronting another woman intent on crossing the picket line. The next day the $\mathrm{Ga}$ zette reported that a woman had been "cautioned" for beating on the car of a female strikebreaker who had taunted union picketers. On May 11 George Scurlock, Local 3's chief steward, tried to rally strikers by using his car to block the path of a bus Wilson and Company used to carry strikebreakers into the plant. Incidents of violence and intimidation also occurred away from the picket line. When a station wagon full of strikebreakers from the nearby town of Vinton tried to go to the Wilson plant in Cedar Rapids, it was met near the Cedar Rapids city limits by a carload of Local 3 members. The strikers stopped the station wagon and tried to convince the potential strikebreakers not to go to the plant. When the latter said they were going to go on to the plant, the strikers slashed their tires. ${ }^{37}$

By mid-May confrontations between strikers, supervisors, and strikebreakers had grown in frequency and intensity. UPWA local union officials and Iowa District 3 officers found it more and more difficult to control unionists' behavior. This was tragically manifested in Waterloo just two days before the UPWA's National Strategy Committee recommended ending the strike. At 5:30 p.m. on May 19, 1948, striking members of Local 46 surrounded Fred Lee Roberts's car as he tried to enter the Rath Packing Company as a replacement worker. As unionists began to rock Roberts's car back-and-forth, he waved a pistol and then shot union member Chuck Farrell through the head, killing him instantly. The same shot wounded Margaret Grayheim. The shooting ignited a riot. ${ }^{38}$

Strikers and their supporters directed their anger at Rath Packing Company and the replacement workers who had been hired to break the strike. They stormed the plant gates, fought

36. Sioux City Journal, 3 May 1948; Cedar Rapids Gazette, 5 May 1948; U.S. Congress, House, Investigation as to the Administration of the Laws Affecting Labor Disputes, 168-69.

37. Cedar Rapids Gazette, 4, 5, and 12 May 1948; Zieren, "'If You're Union, You Stick Together,'" 44-45.

38. The Waterloo Courier provided extensive coverage of the shooting and its aftermath in its issues of 20-23 May 1948. 


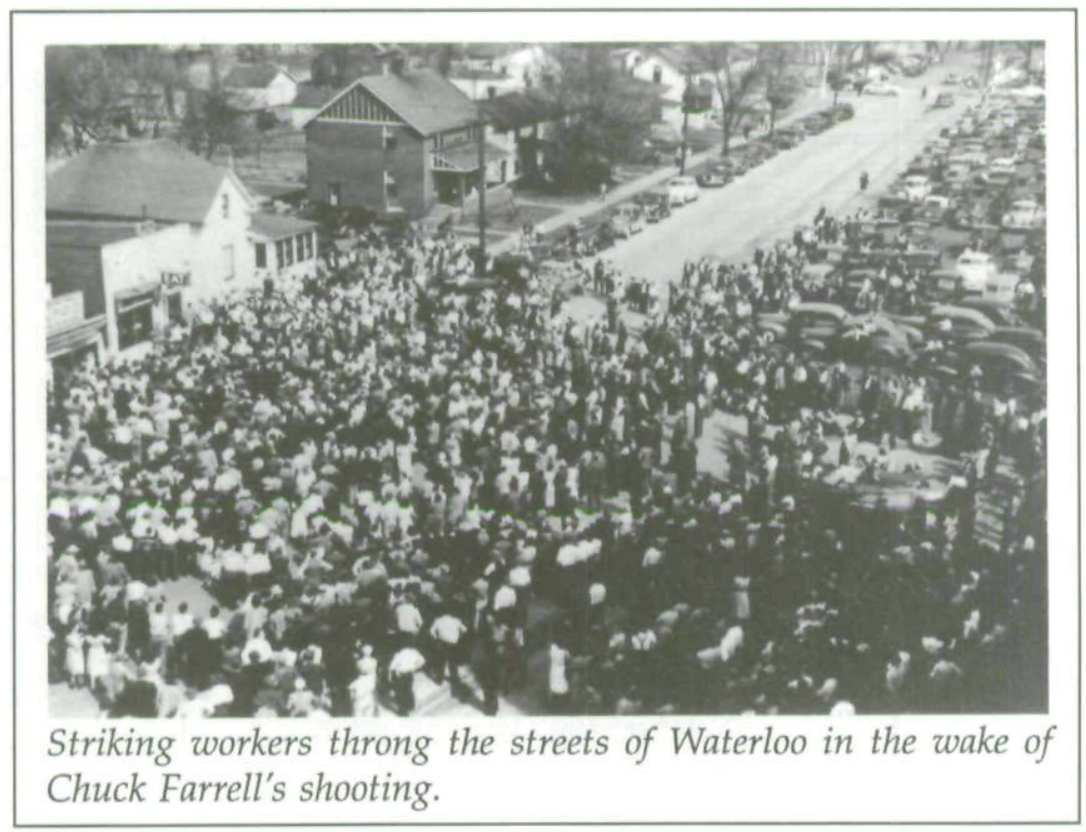

with strikebreakers, vandalized property, and overturned dozens of cars in Rath's parking lot. Although the violence subsided two hours later, a crowd of several thousand remained in the area well past midnight. The facts that Roberts was an African American and the murder victim white exacerbated fears of further violence. Although the shooting outraged union members, it did not cause a racial break within the union. According to Local 46 member Charles Pearson, himself an African American, strikers did not see the shooting in racial terms. Rather, Local 46's much heralded interracial unionism, forged during the previous decade, prevailed over this potentially divisive tragedy. Solidarity among black and white unionists persisted as Governor Robert Blue, in response to calls for help from municipal officials, ordered nearly one thousand National Guard troops to Waterloo to prevent further confrontations between strikers and strikebreakers. ${ }^{39}$

39. Chicago Tribune, 21 May 1948; Cedar Rapids Gazette, 20 May 1948; IHB display, panels 10, 11, and 12; Waterloo Courier, 20 May 1948; Stromquist, Solidarity and Survival, 179-82; Charles Pearson, interview, Waterloo, 17 July 1986, 


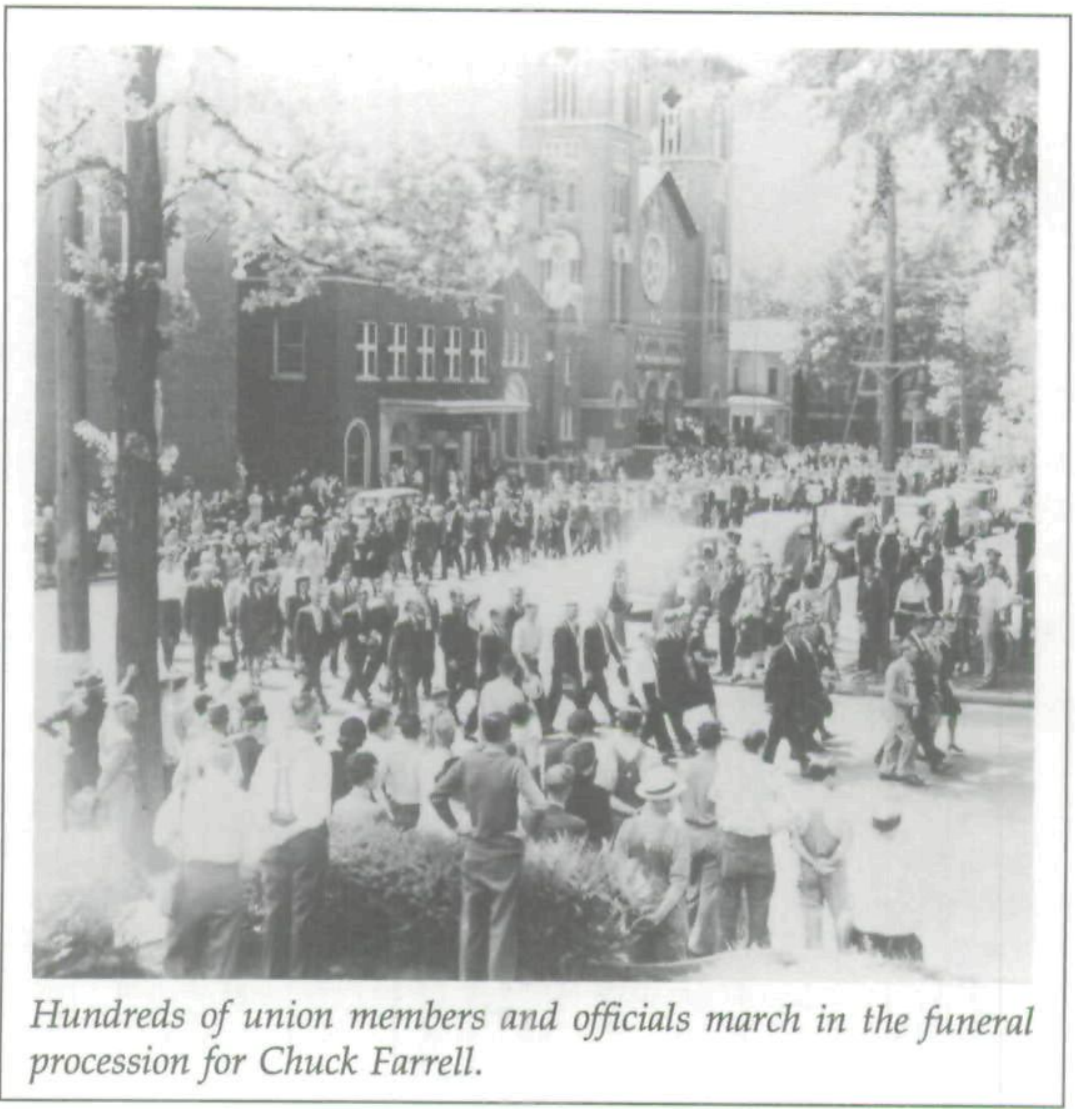

With violence escalating in Iowa and other states, UPWA leaders decided to halt the strike on May 21. In South St. Paul, Minnesota, strikers used fists and clubs to prevent police from enforcing a court injunction against mass picketing. Across the Mississippi River at Newport, Minnesota, strikers overpowered Cudahy company guards, stormed the plant's gates, released livestock, and destroyed property. ${ }^{40}$ As governors in Iowa and Minnesota called out the National Guard, UPWA leaders recognized that union locals were showing signs of exhaustion in several key locales. Subsequently, UPWA officials recommended

UPWAOHP. For a discussion of interracial unionism in Local 46, see also note 52 , below.

40. Newsweek, 24 May 1948, 26; Time, 24 May 1948, 26; Life, 24 May 1948, 29 , 31. 


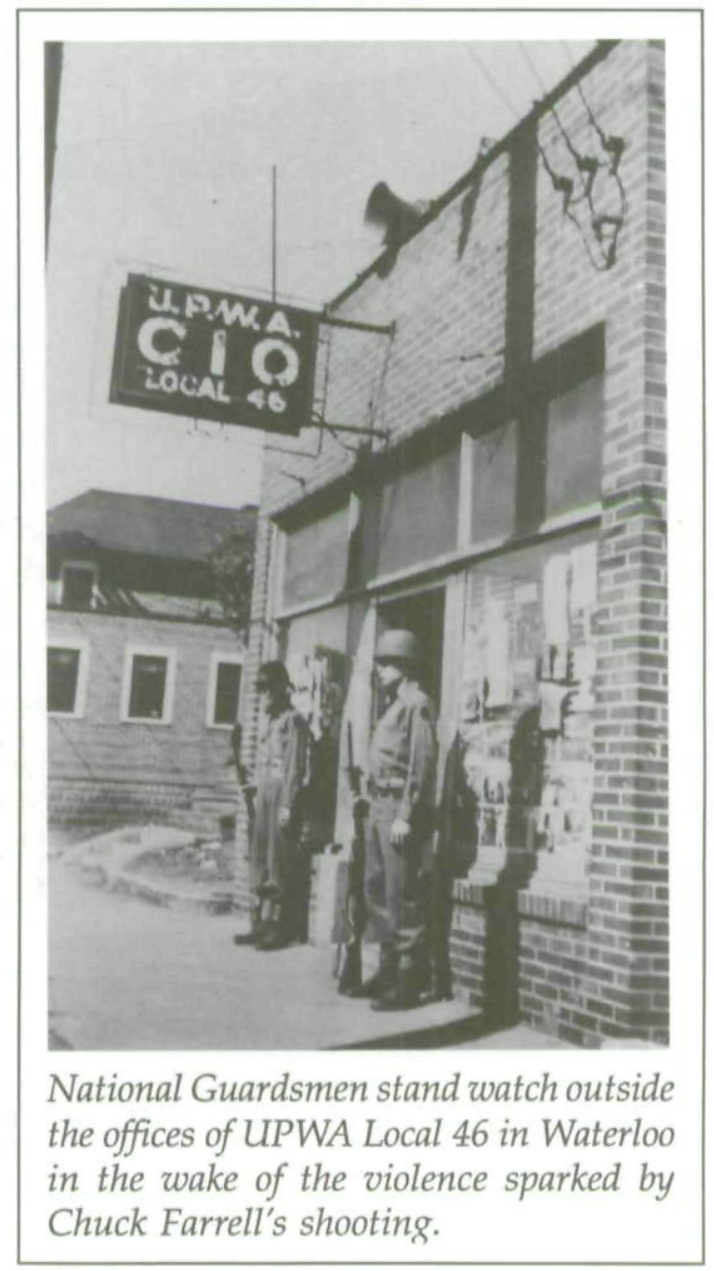

that the membership settle with Swift, Armour, and Cudahy for the original nine-cent per hour wage hike the companies had offered before the strike began. However, union leaders left local unions representing Rath and John Morrell workers free to continue the strike if they chose to do so. In the case of Wilson and Company (one of the Big Four companies), UPWA leaders ordered the strike to continue because the company "insisted on the right to indiscriminately discharge union members without due recourse to the grievance procedure as the contract re- 
quires." Local 3 members in Cedar Rapids followed their leadership's orders to continue the fight against Wilson. ${ }^{41}$

Given the option to remain on strike, Rath Local 46 in Waterloo and John Morrell Local 1 in Ottumwa refused to settle and remained on the picket lines. Local 46 members seemed to feel that the sacrifices they had already made had been too great to permit quitting. Stung by Farrell's death and the occupation by the Iowa National Guard, the membership voted to continue the strike against Rath Packing Company. In a message to Waterloo citizens the day after Farrell's shooting, Local 46 members held Rath Company Executive Director A. D. Donnell responsible for the killing and subsequent riot. The union claimed that Donnell "had created the incidents of yesterday" by obtaining an injunction that forbade the use of the loudspeakers the union had used to control the activities of union picketers and supporters. When Donnell inspected the plant in the riot's aftermath, Local 46 picketers called him a "murderer," shouted "you're responsible for this," and pointed to the spot where Farrell had fallen. One week later, however, Local 46 joined other UPWA locals and accepted the inevitable. It swallowed Rath's original contract offer of a nine-cent wage increase. $^{42}$

DAMAGE FROM THE 1948 STRIKE was great, and the restoration of union power in some of Iowa's local UPWA unions was in serious doubt. Firebrands in Waterloo and Cedar Rapids faced companies determined to discipline or discharge them for strike-related activities. In Cedar Rapids, Wilson and Company fired George Scurlock, Local 3's chief steward, for his interference with company efforts to resume operations during the strike. Scurlock never returned to the Wilson plant. In Waterloo, a grand jury indicted twenty-three people in connection with events following Chuck Farrell's shooting - for conspiracy to incite a riot, malicious mischief, or assault and battery. Two of

41. The Packinghouse Worker, 28 May 1948; Cedar Rapids Gazette, 22 May 1948.

42. The Packinghouse Worker, 28 May 1948. 
Local 46's most active members were convicted and spent time in prison. ${ }^{43}$

To recover from its weakened state and to bolster union members' confidence, the UPWA turned to its traditional source of strength and solidarity, namely, its still powerful steward organizations. Before too long, shop-floor leaders were employing strikes and work slowdowns to reassert control inside plants and win favorable settlement of workers' grievances. ${ }^{44}$

Union members also worked to restore union power and solidarity by relentlessly punishing or ostracizing former strikebreakers. "Oh sure we put pressure on them," recalled Local 46 member Richard Price. "They'd get into their lunch bucket and grab a hog turd and put it in between for a sandwich. Oh, they did atrocious things to them." "As the years went by they never forgot that they were scabs," recalled Ethel Jerred of Ottumwa Local 1. "Even right to this day. If that woman should pass away, I doubt very much whether they would ever say, 'Sweet little Helen.' They'd probably say, 'Helen the scab,' because that's the title she's got. That label stays with you till the day you die." ${ }^{\prime 45}$

In Iowa and other states, the ability of local unions to restore confidence in the strength and solidarity of shop-floor power enabled them to withstand companies' post-strike counterattacks. ${ }^{46}$ The UPWA eventually won reinstatement of all but a handful of discharged workers. In addition, the UPWA withstood challenges from other unions and, by wide margins, won every one of twenty-two subsequent recertification elections held in UPWA-

43. Orear and Diamond, Out of the Jungle; Jesse Prosten, interview, Washington, DC, 18 December 1985, UPWAOHP; Daly, "History of Unionization," 49; Stromquist, Solidarity and Survival, 180-81; Waterloo Courier, 6 May 1984.

44. Waterloo Courier, 14 November 1948; Stromquist, Solidarity and Survival, 206-8; Roger Horowitz, "The Path Not Taken: A Social History of Industrial Unionism in Meatpacking, 1930-1960" (Ph.D. diss., University of WisconsinMadison, 1990), 584-85.

45. Richard Price, interview, ILHOP; Stromquist, Solidarity and Survival, 186; Eldridge, Rath Packing Company Strike, 66.

46. Horowitz, Negro and White, Unite and Fight, 192; Viola Jones interview; George Fletemeyer, interview, South Omaha, NE, 6 June 1986, UPWAOHP. Fletemeyer, a leader of Swift Local 47 in Omaha, recalled that his union's steward system "saved the situation" in the wake of the strike. Stromquist, Solidarity and Survival, 207-8. 
represented plants across the country. ${ }^{47}$ Local 46 , for example, withstood a certification challenge by the National Brotherhood of Packinghouse Workers, winning in 1948 by a margin of four to one. ${ }^{48}$ Furthermore, according to UPWA President Ralph Helstein, the solidarity and determination displayed by the rank-and-file in 1948 influenced companies' concessions in contract negotiations the following year. Of the 1949 settlement with Armour, for example, Helstein recalled, "we had more gains in that contract tha[n] we had ever negotiated with the company. ... We established ... [the] five day guarantee, Saturday overtime, things our people had been wanting for ages." ${ }^{\prime 4}$

UPWA locals in Iowa and other states also used the strike's aftermath as an opportunity to move forward on an agenda to promote the interests of the union's minority members and women. As part of the campaign to repair the union after the strike, the UPWA's international leadership decided to embark on a bold new program to improve the status and fortunes of the union's minority members and women. International President Ralph Helstein and other union leaders were acutely aware of race as a source of potential division among the rank-and-file. After a pivotal strike in 1921 and 1922, companies had effectively played the race card to divide workers, win the strike, and damage the union movement for years to come. So, to maintain the loyalty of its African-American members, the UPWA inaugurated an aggressive antidiscrimination program to eliminate companies' race-based hiring, placement, and discharge practices. ${ }^{50}$

47. UPWA records indicate that the Big Four alone fired 788 union members. See "Report of the Grievance Department," 16 March 1949, UPWA Records. Brody, The Butcher Workmen, 236, calculated that the UPWA ultimately restored the jobs of 541 out of 591 discharged workers. See also Orear and Diamond, Out of the Jungle.

48. Daly, "History of Unionization," 48; Chuck Mueller, interview, Waterloo, 10 May 1986, UPWAOHP.

49. Ralph Helstein, interview, Chicago, 12 May 1983, ILHOP.

50. Horowitz, Negro and White, Unite and Fight, 220-27; Wilson J. Warren, "The Limits of Social Democratic Unionism in Midwestern Meatpacking Communities: Patterns of Internal Strife, 1948-1955," in Stromquist and Bergman, eds., Unionizing the Jungles, 139-46. 
In Iowa, African Americans in Waterloo Local 46 took full advantage of the supportive context created by the leadership's antidiscrimination program. Compared to other Iowa packinghouses, Rath Packing Company had a relatively high percentage of African Americans in its work force, and a number of them had become prominent leaders of Local 46. The UPWA "probably had the strongest policy on race that I've ever been involved with before or since," recalled Jimmie Porter of Local $46 .{ }^{51}$ Porter and other union activists built on the UPWA's tradition of interracial unionism. They organized the Local 46 AntiDiscrimination Department and built a vital program that successfully attacked discriminatory behavior by Rath Company. They also extended their activities into the community and became the most prominent and important bastion for the civil rights struggle in Waterloo. ${ }^{52}$

In the wake of the 1948 strike, the International's AntiDiscrimination Department also established programs to address women's concerns and cultivate women's union participation. During the 1948 strike, Iowa women had stood shoulder to shoulder with men. They had performed most of the critical secretarial work and strike kitchen duty, and they were stalwarts on the picket lines. They had been in the thick of confrontations with strikebreakers, police, and the National Guard. Charles Mueller recalled that in Waterloo "women were right in there banging away at the company just like the men were." ${ }^{153}$

51. Jimmie Porter, interview, Waterloo, 8 May 1986, UPWAOHP.

52. Bruce Fehn, "'The Only Hope We Had': United Packinghouse Workers Local 46 and the Struggle for Racial Equality in Waterloo, Iowa, 1948-1968," Annals of Iowa 54 (1995), 208-13; Rick Halpern and Roger Horowitz, eds., "Looking for the Promised Land: Labor and Civil Rights in Waterloo, Iowa," in Meatpackers: An Oral History of Black Packinghouse Workers and Their Struggle for Racial and Economic Equality (New York, 1996), 136-43; Stromquist, Solidarity and Survival, 155.

53. Charles Mueller, interview, UPWAOHP. See also "Trial Testimony of Dorothy Parker, Pete Jensen, Officer Hobart Mastain, and Margaret Boehmler," box 3, folder 7, Local 46 Papers; "James J. Healy Arbitrator for the 17 Discharge[d] Arising Out of the Strike," 31 August [1948], box 3, folder 2, Local 46 Papers; Dorothy Baker and Iota Hayes, Trial Testimony, box 3, folder 7, Local 46 Papers; Lucille Bremer, interview, Waterloo, 2 June 1982, and Velma Otterman, interview, ILHOP. 
In the 1950s UPWA women repeatedly referred to the 1948 strike to legitimate their demands for equal pay for equal work and greater representation in union offices. After observing women's contributions to the strike, many union men found women's demands for equality reasonable. In 1957 the UPWA attained equal pay for equal work in union contracts. ${ }^{54}$

MOST UPWA MEMBERS viewed their union's strike recovery in favorable terms, yet this massive labor confrontation had long-term, damaging consequences. After the strike, companies began to develop strategies to control labor militancy and frustrate strikes that might shut down production in the entire industry. For example, in the 1950s John Morrell officials began t $)$ hire new workers who resided in rural areas outside Ottumwa. Thiese workers from the countryside had never been acculturated into the union loyalties of Ottumwa's working-class residents. Nor had they "experienced the deeply transforming process of building the unions to which they now paid dues." And, apparently, veteran Local 1 leaders did not successfully cultivate the full union allegiance of this "new generation" of Local 1 members. Since the new workers had not experienced working conditions at John Morrell during the pre-UPWA era, they balked at Local 1's repeated use of "wildcat" strikes to pressure John Morrell. While veterans of the pre-union era regarded such actions as necessary to keep the company "in line" and reinforce union solidarity, new workers perceived them as potentially reducing their paychecks. The overall effect of divisions between veteran unionists and the new employees was a weakening of Local 1's shop-floor power. ${ }^{55}$

Management's determination to undermine union power at the point of production coincided with other developments

54. Fehn, "Striking Women," 214-30. See also Dennis A. Deslippe, "'We Had an Awful Time with Our Women': Iowa's United Packinghouse Workers of America, 1945-1975," Journal of Women's History 5 (1993), 10-32; and Fehn, "'Chickens Come Home to Roost,"' 324-41.

55. Nelson Lichtenstein, Labor's War at Home: The CIO in World War II (Cambridge, 1982), 123 (quotation); Warren, "When 'Ottumwa Went to the Dogs,'" 217-22, 225-30; idem, "Heyday of the CIO," 384-86. 
that eroded the very core of the UPWA's organized strength. In the 1950s new independent meatpacking firms arose to challenge the dominance of the old-line companies such as Morrell, Rath, Swift, and Armour. This "new breed" of meatpackers took advantage of new technologies and established plants near feedlots in rural areas of Iowa and other Corn Belt states. The oldline companies tried to respond to the new competition, but the new meatpacking firms ultimately prevailed. In 1961 the union's research department reported that, during the previous five years, 39,100 packinghouse workers had lost their jobs due to plant closings and companies' technological adjustments. Such losses were heavy blows to the UPWA, and in later decades the blows only became worse. As Armour, Swift, Rath, and other companies closed or cut back on operations, the UPWA's traditional strongholds of union power in Chicago, Kansas City, and elsewhere were virtually eliminated. ${ }^{56}$

Yet the disaster to the union later wrought by fundamental change in the industry in no sense tarnished what UPWA members felt they had accomplished in the wake of the 1948 strike. To some degree, the restoration of union power was a tribute to the local union strength and solidarity the UPWA had established during the 1930s and 40s. Local union members in Iowa and elsewhere had grown accustomed to job actions and strikes to win battles with companies. In these contests, union members relied on one another and experienced the power of collective action. Manifestations of union solidarity were visible throughout the strike as Iowa unionists together stood on picket lines, manned strike kitchens, confronted police, and meted out punishment to strikebreakers. In the strike's aftermath, union veterans renewed membership solidarity by seeking to reestablish the trademark of UPWA power - the steward system. They

56. "Facts and Figures," vol. 14, no. 21, 27 July 1961, folder 14, box 513, UPWA Records. For discussion of the economic transformation of the meatpacking industry, see Horowitz, Negro and White, Unite and Fight, 247-58; Kim Moody, An Injury to All: The Decline of American Unionism (New York, 1988), 179-205; Dorothy Remy and Larry Sawyers, "Economic Discrimination and Stagnation," in My Troubles Gonna Have Trouble with Me: Everyday Trials and Triumphs of Women Workers, ed. Karen B. Sacks and Dorothy Remy (New Brunswick, NJ, 1984), 94-112. 
further enhanced solidarity by breaking down barriers that had divided workers on the basis of race or sex. For years, once again, the UPWA was able to aggressively represent the interests of its members and remind companies that workers, when organized, could build and maintain genuine power in their relations with management-even amidst the adversity engendered by a "lost" strike. 
Copyright of Annals of Iowa is the property of State of Iowa, by \& through the State Historical Society of Iowa and its content may not be copied or emailed to multiple sites or posted to a listserv without the copyright holder's express written permission. However, users may print, download, or email articles for individual use. 